\title{
Author Correction: Truncation of mutant huntingtin in knock-in mice demonstrates exon1 huntingtin is a key pathogenic form
}

Huiming Yang, Su Yang, Liang Jing, Luoxiu Huang, Luxiao Chen, Xianxian Zhao, Weili Yang, Yongcheng Pan, Peng Yin, Zhaohui S Qin (1), Beisha Tang, Shihua Li \& Xiao-Jiang Li (1)

Correction to: Nature Communications https://doi.org/10.1038/s41467-020-16318-1, published online 22 May 2020.

The original version of this Article omitted from the author list the 11th author Beisha Tang, who is from the 'Department of Neurology \& Key Laboratory of Hunan Province in Neurodegenerative Disorders, Xiangya Hospital, Central South University'. Consequently, the following was added to the Author Contributions: 'B.T. sponsored H.Y. to do research at Emory University and provided advice on the experiments'. This has been corrected in both the PDF and HTML versions of the Article.

In addition, the original version of this Article contained an error in the author affiliations. Yongcheng Pan was incorrectly associated with Department of Neurology, The First Affiliated Hospital, Sun Yat-sen University, 510080 Guangzhou, China and their affiliation with Department of Neurology \& Key Laboratory of Hunan Province in Neurodegenerative Disorders, Xiangya Hospital, Central South University was inadvertently omitted. This has now been corrected in both the PDF and HTML versions of the Article.

Published online: 19 November 2020

(c) Open Access This article is licensed under a Creative Commons Attribution 4.0 International License, which permits use, sharing, adaptation, distribution and reproduction in any medium or format, as long as you give appropriate credit to the original author(s) and the source, provide a link to the Creative Commons license, and indicate if changes were made. The images or other third party material in this article are included in the article's Creative Commons license, unless indicated otherwise in a credit line to the material. If material is not included in the article's Creative Commons license and your intended use is not permitted by statutory regulation or exceeds the permitted use, you will need to obtain permission directly from the copyright holder. To view a copy of this license, visit http://creativecommons.org/licenses/by/4.0/.

(C) The Author(s) 2020 